\title{
Effect of Soybean Cyst Nematode on Growth of Dry Bean in the Field
}

\author{
Susilo H. Poromarto, Berlin D. Nelson, and Rubella S. Goswami, Department of Plant Pathology, North Dakota \\ State University, Fargo 58108
}

\begin{abstract}
Poromarto, S. H., Nelson, B. D., and Goswami, R. S. 2010. Effect of soybean cyst nematode on growth of dry bean in the field. Plant Dis. 94:1299-1304.

Phaseolus vulgaris is a host of soybean cyst nematode (SCN; Heterodera glycines), but the effects of SCN on growth of dry bean plants are poorly understood. To study the effects of SCN (HG type 0) on dry bean, the cultivars GTS-900 (pinto bean), Montcalm (kidney bean), and Mayflower (navy bean) were evaluated in eight field experiments at four locations between 2007 and 2009. Plants were grown in a pasteurized Arveson loam soil that was infested with SCN eggs at densities ranging from 0 to 10,000 eggs $/ 100 \mathrm{~cm}^{3}$ soil. Soil was placed in 14.6-liter plastic pots that were buried in the field with the bottoms removed. SCN reproduced on all three dry bean cultivars with reproduction factors $(\mathrm{RF}=$ number of eggs in the soil at harvest divided by number of eggs at planting) ranging from 6.1 to1.2. RFs were higher for dry bean plants growing at lower egg densities compared to higher densities. Pod number (PN), pod weight (PW), seed number (SN), and seed weight (SW) of GTS-900 were significantly less at 5,000 and 10,000 eggs $/ 100 \mathrm{~cm}^{3}$ soil compared with the control. Averaged over those two egg densities, PN, PW, $\mathrm{SN}$, and SW were reduced by 44 to $56 \%$ over the 2 years compared with the control. For Montcalm, significant reductions of 31 to $35 \%$ in PW, SN, SW, and total dry weight (TDW) in treatments of 2,500 and 5,000 eggs/100 $\mathrm{cm}^{3}$ soil were recorded in 2009, but not in 2008. For Mayflower, significant reductions of 27 to $41 \%$ in PH, PW, SN, SW, and TDW in treatments of 2,500 and 5,000 eggs $/ 100 \mathrm{~cm}^{3}$ soil compared with the control were recorded in one out of two experiments in 2009. The reproduction of SCN on roots and the reduction in plant growth and seed yield on three different bean classes under field conditions indicates SCN is a potential threat to the large dry bean industry in the North Dakota-northern Minnesota region.
\end{abstract}

Soybean cyst nematode (SCN), Heterodera glycines Ichinohe (Tylenchida: Heteroderidae), is the most serious pathogen of soybean (Glycine max (L.) Merr.) in the United States and suppresses yield more than any other pathogen (14). SCN reduces yield by feeding on plant nutrients, retarding root growth, reducing water and nutrient uptake and transport from roots to shoots, and inhibiting rhizobial nodulation $(34,44)$. Yield losses can exceed $40 \%$ depending on many factors such as $\mathrm{SCN}$ population density, soil texture and fertility, rainfall, and the presence of susceptible soybean genotypes $(17,18,29)$. The typical aboveground symptoms caused by SCN are stunting, yellowing, and wilting (14), but yield loss occurs without obvious aboveground symptoms (42). In the United States, this nematode was responsible for losses of approximately $\$ 460$ million to $\$ 818$ million per year between 2003 and 2005 (46).

SCN was first observed in China and Japan in the 1880s (14). In 1938, the nematode was reported from Manchuria

Corresponding author: B. D. Nelson

E-mail: berlin.nelson@ndsu.edu

Accepted for publication 18 July 2010.

doi:10.1094/PDIS-05-10-0326

(C) 2010 The American Phytopathological Society and then from several other parts of Asia, including the Amur District in Russia. In the United States, SCN was first reported in 1954 in North Carolina (45) and subsequently spread to 30 states and into Canada with the extension and intensification of soybean cultivation. SCN was first reported in Minnesota in 1978 (21) and is now detected in 55 counties in southern and central Minnesota. In 1995 SCN (race 3) was reported in South Dakota (39), and in 2003 the nematode (HG type 0) was discovered in Richland County, ND, in the southeast corner of the state in the Red River Valley (6).

SCN is spread readily from field to field in soil particles on farm machinery (19). Unfortunately, the agricultural practices in the Red River Valley, specifically in the production, harvesting, and transportation of sugar beets and potatoes which results in considerable movement of soil, will exacerbate the dissemination of SCN in this area. Based on recent measurements of egg populations in infested soils in North Dakota, the nematode reproduces extremely well. In infested fields in Cass and Richland counties, egg counts from 4,000 to more than 20,000 eggs $/ 100 \mathrm{~cm}^{3}$ of soil have been detected in areas of infested fields following a susceptible soybean crop (B. Nelson, unpublished). In some of these infested fields after 4 years cropping to nonhost crops, SCN egg densities greater than 1,000 eggs/100 $\mathrm{cm}^{3}$ have been meas- ured, indicating good survival between susceptible crops. These observations on SCN strongly suggest the nematode will become a widespread and serious pathogen of soybean and other susceptible crops in North Dakota.

North Dakota and northern Minnesota is a major dry edible bean (Phaseolus vulgaris L.) production area with 307,500 ha (760,000 acres) and a production value of $\$ 309$ million in 2009 (3). North Dakota was ranked the number one producer of dry bean in the United States in 2009, with at least 22 varieties of dry beans grown in the area. Dry bean is a host of SCN $(10,25)$, and the nematode can reproduce on dry bean cultivars grown in the region (32). These facts suggest that SCN could be a threat to dry bean production. There is limited research on the biology of SCN on dry bean and no research on the effects of SCN on dry bean production under field conditions. Indeed, we found only two papers that reported effects of SCN on dry bean growth. Becker and Ferraz (5) in Brazil reported that SCN reduced yield and root dry weight in greenhouse experiments. In other greenhouse experiments, Abawi and Jacobsen (1) reported that up to 108 eggs or Juvenile 2 of SCN/cm ${ }^{3}$ of soil did not significantly reduce growth of California Red Kidney bean after 35 days growth in the infested soil. To understand the potential threat of SCN to dry bean production in the United States, information on the effects of the nematode on plant growth under field conditions is needed. The objectives of our study were to determine the effect of SCN on dry bean growth and measure reproduction of $\mathrm{SCN}$ on the roots under field conditions using different dry bean types adapted to this region. A preliminary report of the research has been published (31).

\section{MATERIALS AND METHODS}

Cultivars and field sites. The study was conducted in Richland and Cass counties of North Dakota between 2007 and 2009 using artificially infested soil in plastic pots buried in different field sites. The dry bean cultivars tested were GTS-900 (pinto bean), Montcalm (kidney bean), and Mayflower (navy bean). These cultivars were chosen because they had previously been evaluated for reproduction of $\mathrm{SCN}$ and showed a high level of reproduction within their respective bean class (32). Eight experiments were conducted in the following four locations, with each cultivar being a separate experiment: in 2007 in the Freese 
field (Arveson loam, $\mathrm{pH}$ 7.4) in Richland County with GTS-900; in 2008 in the Ward field (Mantador-Delamere-Wyndmere fine sandy loam, $\mathrm{pH}$ 8.0) in Richland County, with GTS-900 and Montcalm; in 2008 in the Fargo field site 1 (Fargo silty clay, $\mathrm{pH}$ 6.8) in Cass County, with Montcalm and Mayflower; in 2009 in Fargo field site 1 with Montcalm and Mayflower; and in 2009 in Fargo field site 2 (Fargo silty clay) with Mayflower. Planting and harvesting dates were the following: 13 June and 29 September 2007; 16 June and 29 September 2008; and 25 June and 5 October 2009.

Soil from the Freese field was used in the pots in all experiments. This soil was chosen for the experiments because SCN had reproduced to high levels on soybean in this field. Soil from the tillage layer was collected, pasteurized for $3 \mathrm{~h}$ at temperatures $>72^{\circ} \mathrm{C}$, and then placed in 14.6-liter plastic pots (model 2000EG, $28 \mathrm{~cm}$ diameter at top $\times 27.5 \mathrm{~cm}$ height, Nursery Supplies Inc., Portland, OR). SCN eggs were then thoroughly mixed into the soil in each pot. Dry bean seeds were surface-sterilized with $1.0 \% \mathrm{NaOCl}$ for $1 \mathrm{~min}$, rinsed with water, then germinated on seed germination paper for 3 days. Healthy germinating seeds of uniform size were planted $2.5 \mathrm{~cm}$ deep at one per pot in 2007 and 2008 and two per pot for kidney and three per pot for navy bean in 2009. Plants were grown in the pots in the greenhouse for 15 days to establish root systems and then moved to the field where the bottom of each pot was removed as the pots were buried $24 \mathrm{~cm}$ deep in the field soil.

Source of SCN and soil infestation. Eggs of SCN were obtained from the Freese site which was naturally infested with SCN from previous soybean cultivations. The population of SCN was identified as HG type 0 (32) following the methods of Niblack et al. (28). Cysts and eggs were extracted according to methods described previously (32). A suspension of eggs in distilled water was prepared and adjusted to 5,000 eggs $/ \mathrm{ml}$ and immediately added to the soil, which was mixed for several minutes in a 5-cubic-foot electric cement mixer. In May 2007, cysts and eggs were extracted directly from the Freese soil and then mixed into the pasteurized soil in the pots. In 2008 and 2009, eggs from the Freese site were inoculated onto Lee 74 or Barnes soybean, two equally susceptible soybean cultivars, and cysts were produced on plants in the greenhouse (32); then eggs were extracted and used to infest soil in the pots.

Experimental design and data analysis. In 2007 , treatments were $0,5,000$, or $10,000 \mathrm{SCN}$ eggs $/ 100 \mathrm{~cm}^{3}$ soil for GTS900. In 2008, treatments were 0, 2,500, 5,000 , or $10,000 \mathrm{SCN}$ eggs $/ 100 \mathrm{~cm}^{3}$ soil for GTS-900, and 0, 1,000, 2,500, and 5,000 eggs $/ 100 \mathrm{~cm}^{3}$ for Montcalm. In 2009 , treatments were $0,2,500$, and 5,000 SCN eggs/100 $\mathrm{cm}^{3}$ for Montcalm and Mayflower. Each cultivar was a separate experiment. The study was conducted in a randomized complete block design with six replications in 2007 and four in 2008 and 2009. Plant height was recorded on 70-day-old plants. Plants were hand harvested and dried at $35^{\circ} \mathrm{C}$ for 5 days. The dry weight of the aboveground plant and number and weight of pods and seeds were determined. All data were recorded as the mean measurement per plant. Following harvest, the pots were removed from the field, the infested soil from inside the pots was air-dried on a greenhouse bench, mixed thoroughly in the cement mixer for several minutes, and the average number of cysts and eggs $/ 100 \mathrm{~cm}^{3}$ soil was determined from three 100-ml subsamples per replication (32). The data were analyzed by analysis of variance with SAS (SAS
Institute, Cary, NC) and least significant differences (Fisher's protected $F$ test, $\alpha=$ $0.05)$ were calculated following significant $(P \geq 0.05) F$ tests. Transforming the data with $\log _{10}$ did not improve the pattern of the residuals; thus, the nontransformed data were used in the analysis. Data from similar experiments were combined where appropriate.

\section{RESULTS}

SCN reproduction. SCN reproduced on all three dry bean cultivars. In all experiments, the number of cysts and eggs in the soil at harvest for treatments where SCN was added was significantly $(P<0.01)$ higher than in the controls (Table 1). With the exception of the experiment with Mayflower at the Fargo field site 1 in 2009, there were significant $(P<0.05)$ differences among treatments in cyst and egg numbers at harvest with numbers always greater when larger numbers of eggs were added to the soil in the other experiments (Table 1). There was some contamination of the soil in the controls by SCN, and reproduction occurred on plants in the controls.

GTS-900 pinto bean. In 2007, plant height $(\mathrm{PH})$, pod number $(\mathrm{PN})$, pod weight $\mathrm{PW}$ ), seed number (SN), seed weight (SW), and total dry weight (TDW) of the aboveground plant of GTS-900 pinto bean were significantly $(P<0.05)$ less in the two SCN soil infestation treatments compared with the control (Fig. 1A). However, there were no significant differences in those variables between the two soil infestation treatments. Averaged over the two SCN treatments, PH, PN, SW, and TDW were reduced by $42,47,56$, and $54 \%$, respectively, compared with the control, and plants contained only $44 \%$ of the seeds compared with the control. Infected pinto bean plants, especially at the higher egg

Table 1. Numbers of cysts and eggs of soybean cyst nematode produced on dry bean cultivars grown in infested soil at different field sites in North Dakota

\begin{tabular}{|c|c|c|c|c|c|c|}
\hline \multirow[b]{2}{*}{$\begin{array}{l}\text { Treatment } \\
\text { Eggs/100 } \mathrm{cm}^{\mathrm{b}} \text { soil }\end{array}$} & \multicolumn{2}{|c|}{ GTS-900a } & \multicolumn{2}{|c|}{ Montcalm } & \multicolumn{2}{|c|}{ Mayflower } \\
\hline & $\begin{array}{c}2007 \\
\text { Freese }\end{array}$ & $\begin{array}{c}2008 \\
\text { Ward \& Fargo }\end{array}$ & $\begin{array}{c}2008 \\
\text { Ward \& Fargo }\end{array}$ & $\begin{array}{c}2009 \\
\text { Fargo (field 1) }\end{array}$ & $\begin{array}{c}2009 \\
\text { Fargo (field 1) }\end{array}$ & $\begin{array}{c}2009 \\
\text { Fargo (field 2) }\end{array}$ \\
\hline & \multicolumn{6}{|c|}{ Cysts $/ 100 \mathrm{~cm}^{3}$ soil $^{\mathrm{c}}$} \\
\hline $\begin{array}{l}\text { Control } \\
1.000\end{array}$ & 21 & 4 & $\begin{array}{r}8 \\
45\end{array}$ & 33 & 26 & 18 \\
\hline 2,500 & & 37 & 61 & 65 & 77 & 95 \\
\hline 5,000 & 78 & 60 & 80 & 112 & 94 & 125 \\
\hline 10,000 & 95 & 75 & & & & \\
\hline \multirow[t]{2}{*}{$\mathrm{LSD}^{\mathrm{d}}$} & 14 & 14 & 6 & 25 & 39 & 24 \\
\hline & \multicolumn{6}{|c|}{ Eggs $/ 100 \mathrm{~cm}^{3}$ soil $^{\mathrm{c}}$} \\
\hline $\begin{array}{l}\text { Control } \\
1,000\end{array}$ & 2,547 & 553 & $\begin{array}{l}1,023 \\
6,119\end{array}$ & 2,788 & 2,246 & 1,762 \\
\hline 2,500 & & 5,787 & 8,348 & 5,725 & 6,921 & 8,546 \\
\hline 5,000 & 9,567 & 8,986 & 11,061 & 9,797 & 7,346 & 10,783 \\
\hline 10,000 & 11,694 & 12,562 & & & & \\
\hline LSD $^{\mathrm{d}}$ & 1.458 & 2.153 & 850 & 2.075 & 2,463 & 2.117 \\
\hline
\end{tabular}

a GTS-900, Montcalm, and Mayflower are cultivars of pinto, kidney, and navy bean, respectively.

${ }^{\mathrm{b}}$ Soil was infested with eggs at planting. No eggs were added to the soil in the controls, but contamination of the controls with cysts or eggs occurred during the experiments.

${ }^{c}$ Numbers of cysts and eggs at harvest.

${ }^{\mathrm{d}}$ Least significant difference (Fisher's protected $F$ test, $\alpha=0.05$ ). 
density, were stunted and had fewer branches and a less robust appearance compared with the plants in the noninfested soil (Fig. 2).

In 2008, the research was conducted at two field sites and the data were combined for analysis. The PN, PW, SN, and SW of GTS-900 were significantly $(P<0.05)$ less in the two highest $\mathrm{SCN}$ soil infestation levels (5,000 and 10,000 eggs/100 $\mathrm{cm}^{3}$ soil) compared with the control, but there were no significant differences between those two levels (Fig. 1B). However, PH and TDW of aboveground plants were significantly less than the control only when plants were infested with 10,000 eggs $/ 100 \mathrm{~cm}^{3}$ soil. The PH and TDW of plants growing in soil with 10,000 eggs $/ 100 \mathrm{~cm}^{3}$ soil were reduced by 38 and $45 \%$ compared with the control, respectively. Averaged over the two highest SCN treatments, the $\mathrm{PN}, \mathrm{PW}, \mathrm{SN}$, and $\mathrm{SW}$ were reduced by $50,40,51$, and $51 \%$, respectively. SCN infestation at 2,500 eggs/100 $\mathrm{cm}^{3}$ soil did not significantly $(P<0.05)$ reduce growth measurements compared with the control (Fig. 1B).

Montcalm kidney bean. For both field experiments in 2008, none of the plant growth variables were significantly $(P<$ $0.05)$ reduced in the infested soils compared with the control (Fig. 1C). The results were the same whether data from each experiment were analyzed separately or combined. In contrast, in 2009 , there were significant $(P<0.05)$ reductions of PN, PW, SN, SW, and TDW in infested soil compared with the control (Fig. 1D), but there were no significant differences between the two egg levels. The average reduction of $\mathrm{PW}, \mathrm{SN}, \mathrm{SW}$, and TDW in the two treatments was $32,32,31$, and $35 \%$, respectively (Fig. 1D). PN was significantly reduced (by 33\%) only at 5,000 eggs $/ 100 \mathrm{~cm}^{3}$ soil compared with the control.

Mayflower navy bean. Although experiments were conducted at two field locations in 2009 , the data from each experiment were analyzed separately because plant growth at Fargo field 2 was considerably slower and plants did not develop as well or appear as robust as in the other Fargo site. In Fargo field 1, there were significant $(P<0.05)$ reductions of $\mathrm{PH}$, PW, SN, SW, and TDW of Mayflower when grown in soil infested with 2,500 or $5,000 \mathrm{eggs} / 100 \mathrm{~cm}^{3}$ soil compared with the control; however, there were no significant differences among the two treatments (Fig. 1E). Averaged over the two treatments, $\mathrm{PH}, \mathrm{PW}, \mathrm{SN}, \mathrm{SW}$, and TDW were reduced by $27,41,36,37$, and $36 \%$ compared with
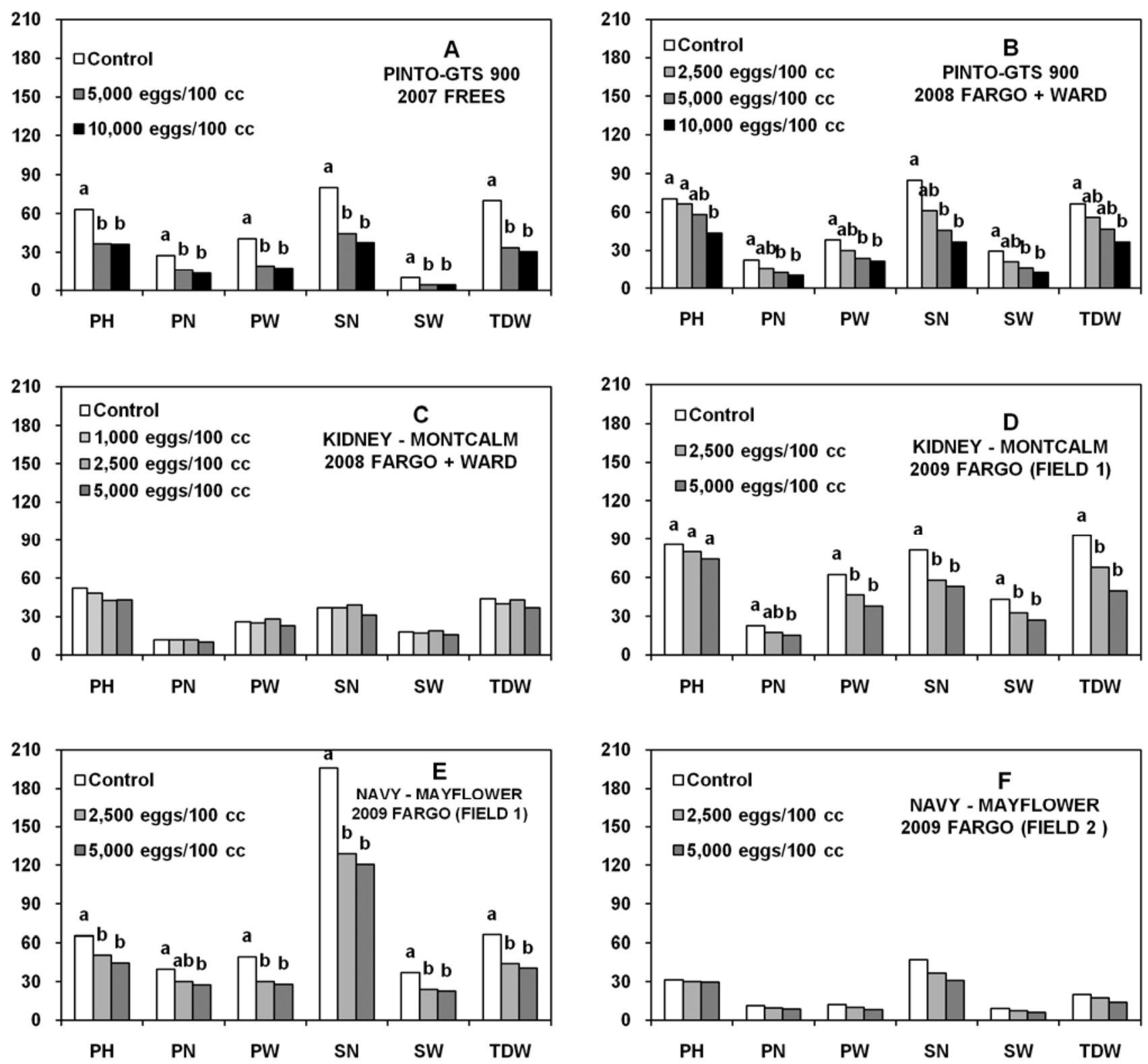

Fig. 1. Effect of soybean cyst nematode on growth of dry bean cultivars. A and B, GTS-900 pinto bean. C and D, Montcalm kidney bean. E and F, Mayflower navy bean. $\mathrm{PH}=$ plant height $(\mathrm{cm}), \mathrm{PN}=$ pod number, $\mathrm{PW}=$ pod weight $(\mathrm{g}), \mathrm{SN}=$ seed number, $\mathrm{SW}=\mathrm{seed}$ weight $(\mathrm{g})$, TDW $=$ total dry weight $(\mathrm{g})$. Bars labeled with the same letter are not significantly different (Fisher's protected $F$ test, $\alpha=0.05$ ). 
the control, respectively. PN was significantly $(P<0.05)$ reduced (by $31 \%)$ in the 5,000 eggs $/ 100 \mathrm{~cm}^{3}$ soil treatment compared with the control, but not at 2,500 eggs $/ 100 \mathrm{~cm}^{3}$ soil (Fig. 1E). In contrast, in Fargo field 2, there were no significant reductions of any growth variables (Fig. $1 \mathrm{~F})$.

\section{DISCUSSION}

These are the first field studies quantifying $\mathrm{SCN}$ reproduction on dry bean and documenting the effect of SCN on growth and yield of this important crop. SCN reproduced on all three dry bean cultivars under field conditions, and the pattern of reproduction was a function of the initial egg density in the soil and host and environmental factors $(24,37,38,40)$. In soybean, the nematode at low population densities is capable of large population increases, whereas at higher egg densities the rate of population increase declines, most likely due to greater competition for feeding sites in root tissue $(2,9)$. In these experiments, the reproduction factors $(\mathrm{RF}$ $=$ number of eggs at harvest time divided by number of eggs at planting time) of SCN were higher in dry bean plants growing at lower egg densities compared with higher densities. In GTS-900 pinto bean, the RFs were $2.3,1.9$, and 1.2 for initial egg densities of 2,500, 5,000, and 10,000 eggs $/ 100 \mathrm{~cm}^{3}$ soil, respectively. For Montcalm kidney bean, the RFs were $6.1,2.8$, and 2.1 for $1,000,2,500$, and 5,000 eggs $/ 100 \mathrm{~cm}^{3}$ soil, respectively, and for Mayflower navy bean, the RFs were 3.1 and 1.8 for egg densities of 2,500 and $5,000 \mathrm{eggs} / 100 \mathrm{~cm}^{3}$ soil, respectively.

The controls in all experiments became infested with SCN sometime during plant growth. Because the Ward and Freese sites were naturally infested with SCN at levels exceeding 3,000 eggs/100 $\mathrm{cm}^{3}$ soil, the pasteurized soil in the pots at those sites

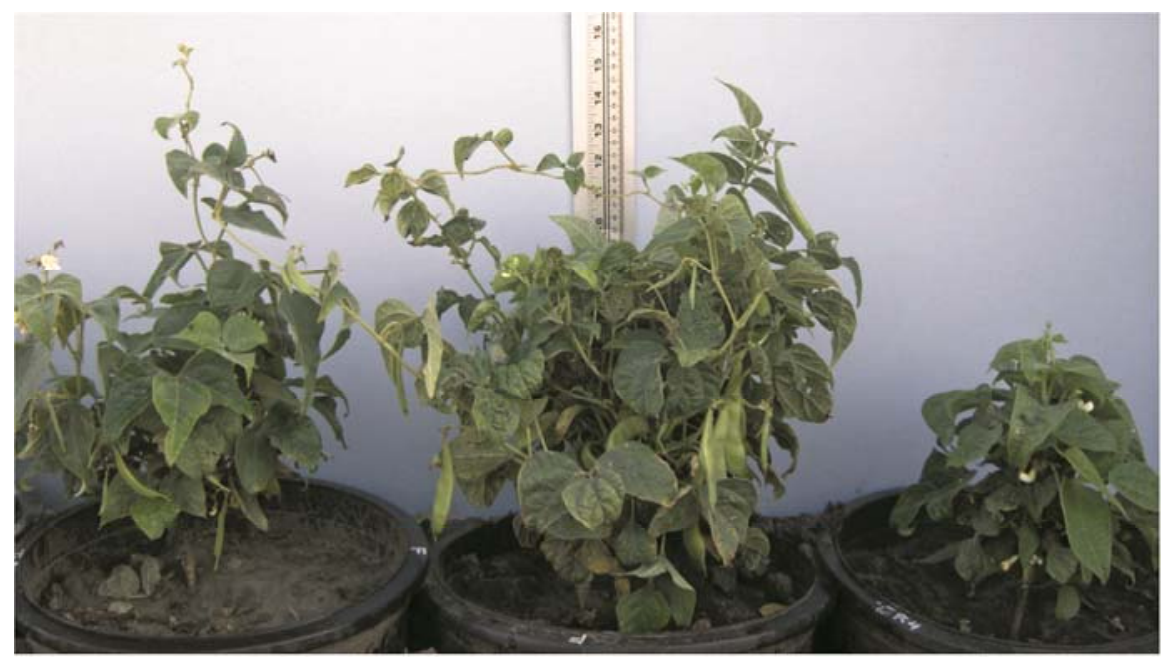

Fig. 2. Effect of soybean cyst nematode on growth of pinto bean in 2007. Plant in the middle is the control growing in soil without eggs added to soil. Plants on the right and left are growing in soil with 10,000 and $5,000 \mathrm{eggs} / 100 \mathrm{~cm}^{3}$ of soil, respectively. Notice the more robust plant growth of the control.

mostly likely became infested with eggs carried in rain splashed or wind driven soil from the area around the pots. In the Fargo sites, however, the soil in the plot areas was not infested with SCN; therefore, it appears that controls may have been infested with SCN from the pots where eggs had been added to the soil. The difference in egg densities detected in the control treatments at harvest was probably due to contamination with eggs at different times during plant growth, an earlier contamination resulting in more cysts and eggs at harvest. Although we pasteurized the soil for $3 \mathrm{~h}$, it is also possible that some eggs might have survived the heat treatment. This natural contamination of the potted soil either by eggs from the surrounding field or by those not killed by pasteurization most likely contributed to the overall reproduction on dry bean roots, but we believe the level of contamination was not sufficient to result in a measurable effect on plant growth.

When we initiated these experiments in 2007, there was no prior research data available on egg densities in soil that might affect the growth of dry bean under field conditions. Therefore, experiments were initiated with relatively high egg densities of 5,000 and 10,000 eggs/100 $\mathrm{cm}^{3}$ soil using a pinto bean cultivar, the most important bean class grown in the North Dakota-Minnesota dry bean production region. Because plant growth was affected by 5,000 and $10,000 \mathrm{eggs} / 100 \mathrm{~cm}^{3}$ soil in 2007 , but there were no significant differences between the two treatments, in following years egg densities of 5,000 eggs $/ 100 \mathrm{~cm}^{3}$ soil or less were evaluated. In previous studies comparing the susceptibility of dry bean cultivars to a susceptible soybean cultivar, kidney bean cultivars were as susceptible as soybean, but navy and pinto bean cultivars were less susceptible (32). Those were also reasons for using the high egg densities in 2007 with pinto bean and the lower egg density of $1,000 \mathrm{eggs} / 100 \mathrm{~cm}^{3}$ soil with kidney bean in 2008 .

Reductions in growth parameters of pinto bean over 2 years of trials point out that SCN can cause significant yield losses in that bean class, with seed number reductions of 45 to $50 \%$ at the higher egg densities. Although in some experiments there were visual differences in infected plants compared with the controls, such as stunting and less robust growth, in others with some treatments no obvious visual differences were apparent, but there was a reduction in yield. Significant yield losses due to SCN without obvious symptoms of disease are well known in soybean $(29,30,42,47)$. One potential reason why plant height and total dry weight at 5,000 eggs/100 $\mathrm{cm}^{3}$ soil were significantly reduced in 2007, but not in 2008, may have been the drier soil conditions in 2007 , which added more stress to infected plants compared with plants growing in the higher rainfall year of 2008 .

The results with Montcalm kidney bean were perplexing. In greenhouse testing, Montcalm was as susceptible to SCN as soybean based on female index, while GTS-900 was less susceptible than Montcalm (32). The fact that there was no reduction in growth of Montcalm at the two sites in 2008 was surprising because 5,000 eggs $/ 100 \mathrm{~cm}^{3}$ soil were used and growth of GTS-900 pinto bean was reduced by SCN at the same two sites. In addition, the egg densities at harvest indicated that SCN reproduced well on Montcalm in 2008. SCN did cause a reduction in growth of Montcalm in 2009. As observed in GTS$900, \mathrm{SCN}$ caused a reduction in growth of Montcalm without any obvious aboveground symptoms. Montcalm may have the ability to support high reproduction of SCN and still yield well under certain conditions, but further studies are needed to verify if this occurs. Similar to Montcalm, there was a reduction in growth of Mayflower navy bean in one experiment, but not the other. The Mayflower plants in Fargo field 2 grew slowly, were never as robust as in field 1, and yields were very low. The cause of the poor growth was not determined, but there were no obvious symptoms of an identifiable disease. Surprisingly, SCN reproduced as well on the Mayflower plants in Fargo field 2 as in field 1 , yet no differences in yield were measured in field 2.

Plant responses to parasitism by nematodes are related to physiological changes that affect the photosynthetic process (15). $\mathrm{SCN}$ is reported to reduce photosynthetic activity on susceptible soybean varieties by lowering the amount of nutrients, particularly nitrogen, either absorbed or translocated by the infected roots (18). Suppression of nodulation of nitrogen-fixing bacteria by SCN has also been demon- 
strated by Ko et al. (16) and Ross (35). Asmus and Ferraz (4) noticed that a reduction in the duration of leaf area caused by SCN correlated with a reduction of yield. Ross (35) reported that besides reducing root nodulation and $\mathrm{N}$ fixation, $\mathrm{SCN}$ causes soybean yield reductions by inciting deleterious host responses that increase with $\mathrm{N}$ deficiency. Physiological changes affecting photosynthetic processes, such as decreased chlorophyll content $(26,27)$, photochemical limitations (36), nutrient imbalance (41), and interference of the synthesis and translocation of photosynthesis regulating factors produced in the roots (20) have been reported to occur during plant response to nematode parasitism (15).

Cyst-forming nematodes are known to affect the growth of crops such as broad bean, chickpea, lentil pea, and vetch $(7,11-$ 13), and $H$. glycines causes substantial damage in soybean $(4,18,22,33,43,47)$. Yield loss in soybean due to SCN is greatly affected by environmental factors such as temperature and moisture and the level of stress on the crop, plus plant variety, soil type, availability of nutrients, and other conditions $(8,17)$. A linear relationship between initial SCN egg number and yield of soybean was reported by Niblack et al. (29) in a 2-year study, but the slope of the predictive line was different for each year even though initial nematode number and cultivar were constant. Similar results were reported by Koenning and Barker (18), where they found different slopes for each year, for irrigated versus nonirrigated plots, and for different soil textures.

This is the first report that SCN can cause a yield loss in dry bean under field conditions and that SCN can reproduce to high levels on dry bean in the field. In five of the eight experiments in this research, SCN caused a reduction in growth of dry bean. The results indicate that SCN poses a potential threat to the dry bean industry in the North Dakota-northern Minnesota growing region. Although SCN has not yet infested the areas where the majority of the dry bean production occurs, it is only a matter of time before $\mathrm{SCN}$ is introduced into those areas. The nematode has been moving north since first reported in southern Minnesota in 1978. In North Dakota, only two southeastern counties, Richland and Cass, are currently known to have infested fields, but these fields are within 50 miles of North Dakota counties with many hectares of dry bean. In northern Minnesota, SCN was recently found in Clay and Norman counties, adjacent to North Dakota, also near dry bean production areas. The reproduction of $\mathrm{SCN}$ on dry bean would suggest that once it is introduced into dry bean fields, egg densities will likely increase quickly in the lighter, sandy soils during warm growing seasons, which are conditions favorable to the nematode. Since dry bean growers in this region are not familiar with this pathogen and yield losses may occur without obvious aboveground symptoms, populations of SCN may build up to high levels and large yield losses could occur before this is recognized as a serious pathogen of dry bean.

The impact that SCN could have on dry bean production in this northern region is unknown. There is limited information on SCN effects on dry bean cultivars in the field, and growers have not yet reported a problem with SCN. Therefore, further research on the SCN-dry bean interaction is warranted, especially on the effects of SCN on dry beans of all classes under field conditions. However, a prudent approach to prepare for the potential management of SCN is to search for resistance to SCN within the $P$. vulgaris germplasm and initiate an educational campaign to inform dry bean growers of this potential threat. Resistance is the principal technique for management of SCN in soybean. Because resistance genes are well known in soybean and there are regions of synteny between the genomes of soybean and dry bean (23), there is a strong possibility of finding resistance genes in the dry bean germplasm. A program to screen germplasm of the various dry bean classes for resistance to SCN has been initiated at North Dakota State University.

\section{LITERATURE CITED}

1. Abawi, G. S., and Jacobsen, B. J. 1984. Effect of initial inoculum densities of Heterodera glycines on growth of soybean and kidney bean and their efficiency as hosts under greenhouse conditions. Phytopathology 74:14701474.

2. Alston, D. G., and Schmitt, D. P. 1987. Population density and spatial pattern of Heterodera glycines in relation to soybean phenology. J. Nematol. 19(3):336-345.

3. Anonymous. 2010. Agricultural Statistics Database. U.S. Dep. Agric. Nat. Agric. Stat. Serv. Online publication.

4. Asmus, G. L., and Ferraz, L. C. C. B. 2002. Effect of population densities of Heterodera glycines race 3 on leaf area, photosynthesis and yield of soybean. Fitopatol. Bras. 27:273278.

5. Becker, W. F., and Ferraz, S. 2004. Efeito da concentração inicial de inóculo do nematóide Heterodera glycines no desenvolvimento do feijoeiro comum. Rev. Agropec. Catarinense, Florianópolis, 17:89-93.

6. Bradley, C. A., Biller, C. R., and Nelson, B. D. 2004. First report of soybean cyst nematode (Heterodera glycines) on soybean in North Dakota. Plant Dis. 88:1287.

7. Di Vito, M., Lamberti, F., and Inserra, R. N. 1978. Effects of Heterodera goettingiana on weight of foliage of pea plants in pots. Nematologica 24:209-212.

8. Donald, P. A., Pierson, P. E., St. Martin, S. K., Sellers, P. R., Noel, G. R., Macguidwin, A. E., Faghihi, J., Ferris, V. R., Grau, C. R., Jardine, D. J., Melakerberhan, H., Niblack, T. L., Stienstra, W. C., Tylka, G. L., Wheeler, T. A., and Wysong, D. S. 2006. Assessing Heterodera glycines-resistant and susceptible cultivar yield response. J. Nematol. 38:76-82.

9. Francl, L. J., and Dropkin, V. H. 1986. Heterodera glycines population dynamics and relation of initial population to soybean yield.
Plant Dis. 70:791-795.

10. Fujita, K., and Miura, O. 1934. On the parasitism of Heterodera schachtii Schmidt on beans. Trans. Sapporo Nat. Hist. Soc. 13:359-364.

11. Greco, N., Di Vito, M., Saxena, M. C., and Reddy, M. V. 1988. Effect of Heterodera ciceri on yield and lentil and development of this nematode on chickpea in Syria. Nematologica 34:98-114.

12. Greco, N., Di Vito, M., Singh, K. B., and Saxena, M. C. 1993. Effect of Heterodera ciceri on the growth of selected lines of Cicer species. Nematol. Mediterr. 21:111-116.

13. Greco, N., Ferris, H., and Brandonisio, A. 1991. Effect of Heterodera goettingiana population densities on the yield of pea, broad bean and vetch. Rev. Nematol. 14:619-624.

14. Hartman, G. L., Sinclair, J. B., and Rupe, J. C., eds. 1999. Compendium of Soybean Diseases. American Phytopathological Society, St. Paul, MN.

15. Hussey, R. S., and Williamson, V. M. 1998. Physiological and molecular aspects of nematode parasitism. Pages 87-108 in: Plant and Nematode Interactions. K. R. Barker, G. A. Pederson, and G. L. Windham, eds. American Society of Agronomy, Madison, WI.

16. Ko, M. P., Barker, K. R., and Huang, J. S. 1984. Nodulation of soybeans as affected by half-root infection with Heterodera glycines. J. Nematol. 16:97-105.

17. Koenning, S. R. 2004. Population biology Pages 73-88 in: Biology and Management of Soybean Cyst Nematode, 2nd ed. D. P. Schmitt, J. A. Wrather, and R. D. Riggs, eds. Schmitt and Associates of Marceline, Marceline, MO.

18. Koenning, S. R., and Barker, K. R. 1995. Soybean photosynthesis and yield as influenced by Heterodera glycines, soil type and irrigation. J. Nematol. 27:51-62.

19. Lal, R., and Lal, A. 2006. Plant parasitic nematodes intercepted from seeds, soil clods and packing material under import quarantine. J. New Seeds 8:49-60.

20. Loveys, B. R., and Bird, A. 1973. The influence of nematodes on photosynthesis in tomato plants. Physiol. Plant Pathol. 3:525-529.

21. MacDonald, D. H., Noel, G. R., and Lueschen, W. E. 1980. Soybean cyst nematode, Heterodera glycines, in Minnesota. Plant Dis. 64:319321.

22. MacGuidwin, A. E., Grau, C. R., and Oplinger, E. S. 1995. Impact of planting 'Bell', a soybean cultivar resistant to Heterodera glycines, in Wisconsin. J. Nematol. 27:78-85.

23. McClean, P. E., Mamidi, S., McConnell, M., Chikara, S., and Lee, R. 2010. Synteny mapping between common bean and soybean reveals extensive blocks of shared loci. BMC Genomics 11:184 doi:10.1186/1471-2164-11184.

24. McSorley, R. 1988. Population dynamics. Pages 109-133 in: Plant and Nematode Interactions. K. R. Barker, G. A. Pederson, and G. L. Windham, eds. American Society of Agronomy, Madison, WI.

25. Melton, T. A., Jacobsen, B. J., and Noel, G. R. 1986. Effects of temperature on development of Heterodera glycines on Glycine max and Phaseolus vulgaris. J. Nematol. 18:468-474.

26. Nagesh, M., and Dhawan, S. C. 1988. Effect of inoculum density of Heterodera avenae on photosynthetic efficiency, chlorophyll, and mineral contents of wheat. Indian J. Nematol. 18:40-43

27. Nehra, S., Sharma, I. R., and Trivedi, P. C. 2001. Effect of different inoculum levels of nematode, Heterodera avenae on photosynthetic efficiency of barley (Hordeum vulgare L.). Asian J. Exp. Sci, 1:1-8

28. Niblack, T. L., Arelli, P. R., Noel, G. R., Opperman, C. H., Orf, J. H., Schmitt, D. P., Shannon, J. G., and Tylka, G. L. 2002. A re- 
vised classification scheme for genetically diverse populations of Heterodera glycines. J. Nematol. 34:279-288.

29. Niblack, T. L., Baker, N. K., and Norton, D. C. 1992. Soybean yield losses due to Heterodera glycines in Iowa. Plant Dis. 76:943-948.

30. Noel, G. R. 1992. History, distribution, and economics. Pages 1-13 in: Biology and Management of the Soybean Cyst Nematode. R. D. Riggs and J. A. Wrather, eds. American Phytopathological Society, St. Paul, MN.

31. Poromarto, S., and Nelson, B. D. 2008. Effects of soybean cyst nematode on growth of pinto bean. (Abstr.) Phytopathology 98:S126.

32. Poromarto, S. H., and Nelson, B. D. 2009 Reproduction of soybean cyst nematode on dry bean cultivars adapted to North Dakota and northern Minnesota. Plant Dis. 93:507-511.

33. Postuka, J. W., Dropkin, V. H., and Nelson, C. J. 1986. Photosynthesis, photorespiration, and respiration of soybean after infection with root nematodes. Photosynthetica 20:405- 410.

34. Riggs, R. D., and Schmitt, D. P. 1987. Nematodes. Pages 757-778 in: Soybean: Improvement, Production, and Uses, 2nd ed. J. R. Wilcox, ed. American Society of Agronomy, Crop Science Society of American, and Soil Science
Society of American, Madison, WI.

35. Ross, J. P. 1969. Effect of Heterodera glycines on yields of nonnodulating soybeans grown at various nitrogen nevels. J. Nematol., Vol. 1, No. 1. 40-42.

36. Schans, J., and Arntzen, F. K. 1991. Photosynthesis, transpiration and plant growth characters of different potato cultivars at various densities of Globodera pallida. Neth. J. Plant Pathol. 97:297-310.

37. Seinhorst, J. W. 1986. Effects of nematode attack on the growth and yield of crop plants. Pages 191-209 in: Cyst Nematodes. F. Lamberti and C. E. Taylor, eds. Plenum Press, New York.

38. Seinhorst, J. W. 1970. Dynamics of populations of plant parasitic nematodes. Annu. Rev. Phytopathol. 8:131-156.

39. Smolik, J. D., Jones, J. L., Gallenberg, D. L., and Gille, J. P. 1996. First report of Heterodera glycines on soybean in South Dakota. Plant Dis. 80:224.

40. Steele, A. E. 1974. Population dynamics of Heterodera schachtii on tomato and sugarbeet. J. Nematol. 7:105-111.

41. Wallace, H. R 1974. The influence of rootknot nematode, Meloidogyne javanica, on pho- tosynthesis and on nutrient demand by roots of tomato plants. Nematologica 20:27-33.

42. Wang, J., Niblack, T. L., Tremain, J. A., Wiebold, W. J., Tylka, G. L., Marett, C. C., Noel, G. R., Myers, O., and Schmidt, M. E. 2003 Soybean cyst nematode reduces soybean yield without causing obvious aboveground symptoms. Plant Dis. 87:623-628

43. Wheeler, T. A., Pierson, P. E., Yound, C. E. Riedel, R. M., Wilson, H. R., Eisley, J. B Schmitthenner, A. F., and Lipps, P. E. 1997 Effect of soybean cyst nematode (Heterodera glycines) on yield of resistant and susceptible soybean cultivars grown in Ohio. Suppl. J. Nematol. 29:703-709.

44. Williamson, V. M., and Hussey, R. S. 1996. Nematode Pathogenesis and Resistance in Plants. Plant Cell 8:1735-1745.

45. Winstead, N. N., Skotland, C. B., and Sasser, J. N. 1955. Soybean-cyst nematode in North Carolina. Plant Dis. Rep. 39:9-11.

46. Wrather, J. A., and Koening, S. R. 2006. Estimates of disease effects on yields in the United States 2003 to 2005. J. Nematol. 38:173-180.

47. Young, L. D. 1996. Yield loss in soybean caused by Heterodera glycines. Suppl. J. Nematol. 28:604-607. 